devoid of academic merit or purpose. I hope that in the future the Bulletin includes articles based on their merit, not on the perceived need to incorporate spurious positions.

Sincerely,

Brian Wood

Professor Rita Simon stands by ber review-[Ed.]

\title{
On John Wansborough
}

15 July 2007

To the Editor,

In your December 2006 issue [volume 40(2):197-199], Fred M. Donner's interesting "retrospective review" of Patricia Crone and Michael Cook's Hagarism (1977) gives no credit to the late John Wansbrough for doing at least as much as them to wake up "the then rather sleepy ficld of early lslamic studies," with his enigmatic, even hermetic contributions Quranic Studies (1977) and The Sectarian Milieu (1978). In the same issue, Mohamad Nasrin misspells his name as 'Warnsbrough' in an informative but rather patronizing review of the recent reprint of Quranic Studies [pp. 250-251].

Has Wansbrough now become $a l$-ab ad, the absent one, whose name is not mentioned, or, if it is, admonishingly mangled? In any case, a thorough critical appraisal of this reputed incendiary among scholars is surely overdue.

Sincerely,

Jonathan Benthall

Honorary Research Fellow

Department of Anthropology

University College London

\section{Donner Replies}

To the Editor,

Professor Jonathan Benthall's letter rightly suggests that the late John Wansbrough, like the authors of Hagarism, offered revisionist ideas about early Islam that shook the traditional views of Islam's origins to their foundations. I did not mention his work in my review simply because that review was of Hagarism, not of all relevant recent research on early Islam. It was not meant as a slight of Wansbrough or his contribution.

I would have to differ with Prof. Benthall, however, on the relative impact of Hagarism and of Wansbrough's two books. As Prof. Benthall suggests, Wansbrough's Qur'anic Studies and The Sectarian Milieu were written in exceedingly difficult prose (he himself calls them "hermetic"). I think that, by themselves, these books would have changed a significant segment of scholarly opinion only very slowly, for the simple reason that few readers would have had the fortitude to read and digest 
them fully. Hagarism, by comparison, while not exactly easy to read, nonetheless presents its main arguments quite clearly, and this made its impact both immediate and profound.

An interesting question is why Wansbrough chose to write his two books, containing such revolutionary ideas, in such an opaque manner. That it was a deliberate choice on his part seems evident when one considers his other writings (for example, on Arabic dialects or Ugaritic trade), which are cast in an absolutely lucid and direct English prose.

Another interesting question, to which I also do not know the answer, is what the exact relationship was among Wansbrough, Cook, and Crone. All of them espoused fundamentally revisionist ideas about Islam's origins, and all of them were in London (and at SOAS) at about, or exactly, the same time in the early-mid 1970s. It is hard to believe that all three came to their ideas completely independently of one another, but who contributed what, or who inspired whom, and in what ways, would be interesting to know. It is important to note, of course, that while they shared the view that the traditional view of Islam's origins was misleading, they differed among themselves on numerous specific points.

As for Wansbrough's longer-term impact, we certainly should not fear that he has become what Prof, Benthall terms the "absent one," for he has today a number of fervent supporters among academic specialists in early Islam and the Qur'an (also some opponents, of course), and his works are regularly cited in scholarship on these subjects. I think there is no question that, over the longer haul, his works will be granted the position in the history of scholarship that the merit of their ideas warrants. That evaluation is, however, still taking place today.

Fred M. Donner

Professor of Near Eastern History

The Oriental Institute and

Department of Near Eastern Languages \& Civilizations

The University of Chicago 